\title{
Some Observations on the Metabolites of Phoma Species
}

\author{
Chikako Takahashi, Setsuko Sekita, Kunitoshi Yoshihira, Shinsaku Natori, \\ Shun-IChi Udagawa, Hiroshi Kurata, ${ }^{i a}$ ) Makoto Enomoto, \\ Kohichiro Ohtsubo, Makoto Umeda, \\ and MAMORU SAITO ${ }^{16)}$ \\ National Institute of Hygienic Sciences ${ }^{1 a}$ and Institute of \\ Medical Sciences, University of Tokyo ${ }^{1 b}$ )
}

(Received April 2, 1973)

\begin{abstract}
Fifteen strains of Phoma species were examined for their production of toxic metabolite(s). Although three of them showed the toxicity for cultured HeLa cells and mice and the metabolites were not identical with the known metabolites, attempts to isolate toxic principle(s) were abandoned due to their instability. In the course of the work cynodontin $^{2)}$ (3), 6-methylsalicylic acid, an unidentified phenolic of $\mathrm{mp} 191-193^{\circ}$, and a chromanone (4) were isolated. The chromanone (4) was proved to be $(2 R)$-5-hydroxy6-(2'-hydroxyethyl)-7-methoxy-2-methylchromanone. ${ }^{3)}$
\end{abstract}

In our course of screening programme of mycotoxin-producing fungi ${ }^{4-6)}$ we encountered some strains of Phoma species (Sphaeropsidales, Fungi Imperfecti) exhibiting cytotoxicity on $\mathrm{HeLa}$ cells and acute toxicity on mice. Phoma is a fungus genus consisting of more than 1700 species that are worldwide in their distribution. Most species of Phoma parasitize host plants, including many kinds of agricultural crops. Some species of the genus are isolated commonly from cereal grains as a seed-borne origin. As far as the authors are aware, there has been no mycotoxin-producing species belonging to the genus hitherto described. ${ }^{7,8)}$ As for the metabolites of Phoma spp. several anthraquinones, ${ }^{2,9)}$ phomazarine, ${ }^{10)}$ epoxydone ${ }^{11)}$ (phyllosinol), ${ }^{12)}$ phomalactone, ${ }^{13)}$ phomin $(\mathbf{1})^{14)}$ (cytochalasin $\mathrm{B}^{15)}$ ), 5-dehydrophomin $(\mathbf{2})^{14)}$ (cytochalasin $\left.\mathrm{A}^{15}\right)$, gentisyl alcohol, ${ }^{16)}$ toluhydroquinone, ${ }^{16)}$ and chlorogentisyl alcohol ${ }^{16)}$

1) Location: a) Kamiyoga-1-chome, Setagaya-ku, Tokyo; b) Shirokanedai-4-chome, Minato-ku, Tokyo.

2) D.E. Wright and K. Schofield, Nature, 188, $233(1960)$; K. Schofield and D.E. Wright, J. Chem. Soc., 1965, 6642.

3) W.J. McGahren, G.A. Ellstad, G.O. Morton, and M.P. Kunstmann, J. Org. Chem., 37, 1636 (1972).

4) M. Saito, K. Ohtsubo, M. Umeda, M. Enomoto, H. Kurata, S. Udagawa, F. Sakabe, and M. Ichinoe, Japan. J. Exptl. Med., 41, 1 (1971).

5) S. Natori, S. Sakaki, H. Kurata, S. Udagawa, M. Ichinoe, M. Saito, M. Umeda, and K. Ohtsubo, Appl. Microbiol., 19, 613 (1970).

6) S. Natori, S. Sakaki, H. Kurata, S. Udagawa, M. Ichinoe, M. Saito, and M. Umeda, Chem. Pharm. Bull. (Tokyo), 18, $2259(1970)$.

7) C.E. Main and P.B. Hamilton, Appl. Microbiol., 23, 193 (1972).

8) H. Tsunoda, Proc. UJNR Conference on Toxic Microorganisms, 1968, Honolulu, 1970, p. 143.

9) I.R.C. Bick and C. Chee, Biochem. J., 98, 112 (1966).

10) F. Kögl and J. Sparenburg, Rec. Trav. Chim., 59, 1180 (1940); F. Kögl and F.W. Quackenbuch,ibid., 63, 251 (1944) ; F. Kögl, G.C. Wessem, and O.J. Elsbach, ibid., 64, 23 (1945); A.J. Birch, D.N. Butler, and R.W. Richards, Nature, 190, 441 (1961).

11) A. Closse, R. Mauli, and H.P. Sigg, Heli. Chim. Acta, 49, 204 (1966).

12) S. Sakamura, H. Niki, Y. Obata, R. Sakai, and T. Matsumoto, Agric. Biol. Chem., 33, 698 (1969).

13) R.H. Evans, G.A. Ellstad, and M.P. Kunstmann, Tetrahedron Letters, 1969, 1791; I. Yamamoto, H. Suide, T. Hemmi, and T. Yamano, J. Takeda Res. Lab., 29, 1 (1970).

14) W. Rothweiler and Ch. Tamm, Experientia, 22, 750 (1966); W. Rothweiler and Ch. Tamm, Helv. Chim. Acta, 53, 696 (1970); G.M. McLaughlin, G.A. Sim, J.R. Kiechel, and Ch. Tamm, Chem. Comm., $1970,1398$.

15) D.C. Aldridge, J.J. Armstrong, R.N. Speake, and W.B. Turner, Chem. Comm., 1967, 26; D.C. Aldridge, J.J. Armstrong, R.N. Speake, and W.B. Turner, J. Chem. Soc. $(C), 1967,1667$.

16) M. Séquin-Fray and Ch. Tamm, Helv. Chim. Acta, 54, 851 (1971). 
have been reported but none of them seems to be causative agent for the toxicity except 1 and 2 , which have shown to exhibit remarkable cytotoxicity. ${ }^{14,15}$ )

In order to clarify the toxic metabolite(s) of the genus, fifteen strains of Phoma isolated from foodstuffs and identified in our laboratory (Table I) were examined. After 3 weeks' incubation on potato-dextrose medium, the mycelium and the filtrate were separated and the filtrate and chloroform extract of the mycelium were applied for toxicity tests for mice and HeLa cells by the methods reported previously. ${ }^{4-6)}$ The filtrate was successively extracted with chloroform and ethyl acetate and the three extracts thus obtained were examined by thin-layer chromatography (TLC) using phomin (1), dehydrophomin (2), and phomalactone as the standards.

Table I. Source of Strains of Phoma species and Their Toxicity on HeLa Cells and on Mice

\begin{tabular}{|c|c|c|c|c|c|c|c|}
\hline \multirow{2}{*}{$\begin{array}{l}\text { Strain } \\
\text { No. }\end{array}$} & \multirow{2}{*}{$\begin{array}{l}\text { Isolate } \\
\text { No. }\end{array}$} & \multicolumn{2}{|c|}{ Samples isolated: } & \multicolumn{2}{|c|}{ Toxicity on HeLa cells $a$ ) } & \multicolumn{2}{|c|}{ Toxicity on mice } \\
\hline & & Source & Locality & Filtrate & Mycelium & Filtrate & Mycelium \\
\hline NHL7003 & $69-\mathrm{SA}-12$ & $\begin{array}{l}\text { fermented } \\
\text { pickles }\end{array}$ & $\begin{array}{l}\text { Saku-shi, } \\
\text { Nagano-ken }\end{array}$ & - & - & - & - \\
\hline 7004 & $69-\mathrm{SA}-13$ & $\begin{array}{l}\text { fermented } \\
\text { pickles }\end{array}$ & $\begin{array}{l}\text { Saku-shi, } \\
\text { Nagano-ken }\end{array}$ & - & + & \pm (liver) & - \\
\hline 7005 & 69-SA-180 & wheat flour & $\begin{array}{l}\text { Saku-shi, } \\
\text { Nagano-ken }\end{array}$ & - & - & - & $+\begin{array}{r}\text { (kidney } \\
\text { thymus) }\end{array}$ \\
\hline 7006 & 69-SA-181 & milled rice & $\begin{array}{l}\text { Saku-shi, } \\
\text { Nagano-ken }\end{array}$ & \pm & \pm & - & $\pm \underset{\text { cells) }}{\text { (proliferating }}$ \\
\hline 7007 & 69-SA-182 & cowpea & $\begin{array}{l}\text { Saku-shi, } \\
\text { Nagano-ken }\end{array}$ & - & \pm & - & - \\
\hline 7008 & $68-\mathrm{AO}-70$ & milled rice & $\begin{array}{l}\text { Amami-oshima Is. } \\
\text { Kagoshima-ken }\end{array}$ & s., Ht & - & $\begin{array}{l}\text { Ht (acute death, } \\
\text { thymus, } \\
\text { proliferating } \\
\text { cells) }\end{array}$ & - \\
\hline 7009 & $68-\mathrm{GO}-161$ & adzuki bean & $\begin{array}{l}\text { Goto Is., } \\
\text { Nagasaki-ken }\end{array}$ & H & - & $\begin{array}{l}\text { \# (acute death, } \\
\text { thymus, } \\
\text { proliferating } \\
\text { cells) }\end{array}$ & - \\
\hline 7011 & 68-GO-164 & adzuki bean & $\begin{array}{l}\text { Goto Is., } \\
\text { Nagasaki-ken }\end{array}$ & + & - & $\begin{array}{l}+ \text { (thymus, } \\
\text { proliferating } \\
\text { cells) }\end{array}$ & \pm (thymus) \\
\hline 7014 & $70-\mathrm{HO}-66$ & wheat flour & $\begin{array}{l}\text { Shizunai-machi, } \\
\text { Hidaka-gun, } \\
\text { Hokkaido }\end{array}$ & - & - & - & - \\
\hline 7015 & $\mathrm{FF}-16-\mathrm{C}$ & $\begin{array}{l}\text { frozen } \\
\text { vegetables }\end{array}$ & Tokyo & - & \pm & - & $\begin{array}{l} \pm \text { (thymus, } \\
\text { lymph node) }\end{array}$ \\
\hline 7016 & $\mathrm{FF}-21-\mathrm{C}$ & $\begin{array}{l}\text { half-cooked } \\
\text { frozen } \\
\text { product }\end{array}$ & Tokyo & \pm & \pm & - & - \\
\hline 7017 & $\mathrm{FF}-33-\mathrm{C}$ & $\begin{array}{l}\text { frozen } \\
\text { shrimp }\end{array}$ & Tokyo & \pm & - & \pm (liver) & - \\
\hline 7018 & $\mathrm{FF}-34-\mathrm{C}$ & frozen oyster & Tokyo & \pm & \pm & $\begin{array}{l} \pm \text { (liver, } \\
\text { kidney) }\end{array}$ & + (stomach) \\
\hline 7019 & $\mathrm{FF}-42-\mathrm{C}$ & $\begin{array}{l}\text { frozen } \\
\text { dasheen }\end{array}$ & Tokyo & 一 & - & - & $\pm \underset{\text { cells) }}{\text { (proliferating }}$ \\
\hline 7020 & $70-\mathrm{NU}-20$ & peanut & $\begin{array}{l}\text { Kebil, Chimbu } \\
\text { Dist., Papua } \\
\text { and New Guinea }\end{array}$ & \pm & + & - & + (thymus) \\
\hline
\end{tabular}

a) Criteria employed for estimating the degree of toxicity is same as the previous paper.4)

Although none of the strains showed the production of these known metabolites, the filtrates of three strains (NHL 7008, 7009, and 7011) showed toxicity both on mice and HeLa cells as follows: The mice died after 1 to 3 intraperitoneal injections of the culture filtrates $(0.8 \mathrm{ml} / 20 \mathrm{~g}$ body weight) on successive days, though histological changes were rather poor 
and inconstant. Thymus cells were invariably damaged showing karyorrhexis. Non-suppurative peritonitis was an occasional finding, even in the mice which were not fatal. HeLa cells were led to necrosis after 3-days' treatment with $3.2 \%$ (NHL 7011) or $0.32 \%$ (NHL 7009 and 7008) of the respective filtrates. The morphological appearance of moderately damaged cells was not characteristic; irregularity in cell size, formation of multinuclear cells, and others. Mitotic figures were preserved. The extract of the mycelium did not show noticiable toxicity (Table I):<smiles>[R]C(C)C=CC=CC1C(O)C(=C)C(C)C(C=CCC(C)C)C1NC(=O)c1ccccc1</smiles>

$1: \mathrm{R}:>\mathrm{H}$ $2: \mathrm{R}:=\mathrm{O}$<smiles></smiles>

3<smiles>[R]OCCc1c(OC)cc2c(c1[R])C(=O)C[C@@H](C)O2</smiles>

$4: \mathrm{R}: \mathrm{R}^{\prime}: \mathrm{H}$

$5: \mathrm{R}: \mathrm{R}^{\prime}: \mathrm{CH}_{3}$

$6: \mathrm{R}: \mathrm{H}, \mathrm{R}^{\prime}: \mathrm{COCH}_{3}$<smiles>COc1cc(O)c2c(c1O)OC(C)CC2=O</smiles>

7<smiles>COc1cc2c(c(O)c1CCO)C(=O)OC(C)C2</smiles>

8<smiles></smiles>

10

11

Chart 1

From these findings further attempts to isolate toxic principle(s) were carried out using the strain NHL 7008. However in the course of an incubation in large scale or subculturing, we encountered the loss of acute toxicity on mice, though the cytotoxicity on HeLa cells had been retained $\left(3.2 \mu \mathrm{g} / \mathrm{ml}\right.$ for $\mathrm{CHCl}_{3}$ extract). Furthermore, when the filtrate was treated successively with $\mathrm{CHCl}_{3}$, EtOAc, and charcoal chromatography, none of the separated fractions showed cytotoxicity, probably due to the decomposition in the course of separation. Under such instability of the toxic principle(s) further attempt was abandoned.

In the course of studies one of the strains NHL 7017 was noticed by pigment formation. From chloroform extract of the mycelium cynodontin ${ }^{2)}(\mathbf{3})$ was isolated and identified. From the culture filtrate of the toxic strain NHL 7008, 6-methylsalicylic acid and an unidentified phenolic with no toxicity, $\mathrm{mp} 191-193^{\circ}, \mathrm{C}_{15} \mathrm{H}_{16} \mathrm{O}_{7}$, were isolated.

From the filtrate of another strain NHL 7018 a phenolic (4), mp $190-191^{\circ},[\alpha]_{D}^{18.5}+24.8^{\circ}$ $(\mathrm{MeOH}), \mathrm{C}_{13} \mathrm{H}_{16} \mathrm{O}_{5}$, was isolated. It forms dimethyl ether (5) (by methyl iodide) and monoacetate (6). From the ultraviolet spectrum (UV) $\left(\lambda_{\max }^{\text {Exor }}: 240,288,325 \mathrm{~nm}\right)$ and infrared spectrum (IR) ( $\nu_{\max }^{\mathrm{KBr}}: 3320,1640,1590 \mathrm{~cm}^{-1}$ ) (in 5, $\nu_{\max }^{\mathrm{KBr}}: 1685,1600 \mathrm{~cm}^{-1}$ ) the compound was assumed to be an 0 -hydroxyarylketone. Nuclear magnetic resonance (NMR) spectra of $\mathbf{4 , 5}$, and 6 including decouplings disclosed the presence of one each of hydroxyethyl, phenolic hydroxyl, methoxyl, ring hydrogen, and $-\mathrm{CH}_{2}-\mathrm{CH}(-\mathrm{O}-)-\mathrm{CH}_{3}$ groups in the compound (Table II). The four structures 4, 7, 8, and 9 suffice these observations. ${ }^{17)}$ In order to distinguish the chromanone $(4,7)$ and the 3,4-dihydroisocoumarin $(\mathbf{8}, \mathbf{9})$ structures, the circular dichroism (CD)

17) The methoxyl group was placed to mieta to the hydroxyl group from biogenetical back ground. 


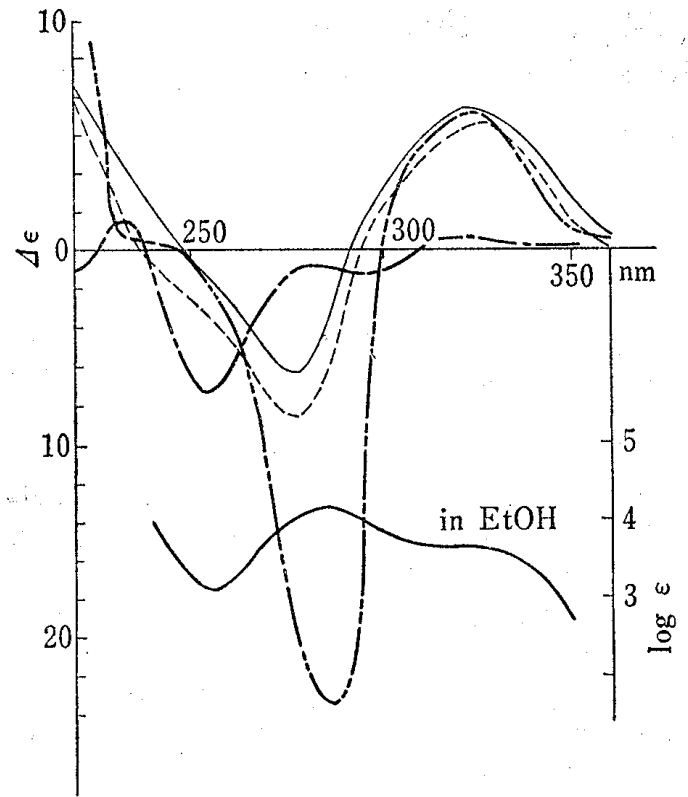

Fig. 1. $\mathrm{CD}$ (in $\mathrm{MeOH}$ ) and UV of the Chromanone 4 and the Related Compounds

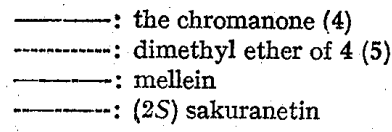

curves of 4 and 5 were compared with mellein (10) and flavanones. ${ }^{18)}$ As shown in Fig. 1, the compounds (4 and 5) showed a negative Cotton effect at the $\pi \rightarrow \pi^{*}$ transition and a positive effect at $n \rightarrow \pi^{*}$ transition superimposable with $2 S$-flavanones. Thus the compound was established to be a chromanone and at the same time the absolute configuration at 2-position was shown to be $R$.

Although there existed no decisive evidence to distinguish the structures 4 and $\mathbf{7}$, we rather favoured the latter from the observation of nuclear Overhauser effects (cf. Table II) of $\mathbf{4}$ and 5 and proposed the structure. ${ }^{19)}$ Just after that isolation of three novel chromanones, LL-D253 $\alpha$, $-\beta$, and $-\gamma$ from Phoma pigmentivora was reported and the structures were elucidated as $\mathbf{4 , 6}$, and $\mathbf{1 1}$ respectively. ${ }^{3)}$ Direct comparison of our sample and the acetate with LL-D253 $\alpha$ and $-\beta$ respectively showed identity. The American chemists discriminate the structure (4) from 7 for their LL-D253 $\alpha$ by the fact that the compound forms

TABLE II. NMR Spectra of the Chromanone (4) and the Derivatives

\begin{tabular}{|c|c|c|c|c|}
\hline $\begin{array}{l}\text { Compound } \\
\text { solvent }\end{array}$ & $\stackrel{4}{\mathrm{CD}_{3} \mathrm{OD}}$ & $\stackrel{\mathbf{5}}{\mathrm{CDCl}_{3}}$ & $\mathrm{CD}_{3}^{6} \mathrm{OD}$ & Coupling \\
\hline $\mathrm{CH}_{3}$ & $1.45^{a)}$ & 1.45 & 1.45 & $\mathrm{~d}, J=6$ \\
\hline$-\mathrm{O}-\mathrm{CH}_{1}^{\prime}$ & $4.44^{a)}$ & 4.35 & 4.40 & $\mathrm{qt}, J=6,8$ \\
\hline $\mathrm{CH}_{1}$ & $2.52^{a)}$ & 2.56 & 2.52 & $\mathrm{~d}, J=8$ \\
\hline$-\mathrm{OR}$ & $\begin{array}{c}\mathrm{R}=\mathrm{H} \\
-\end{array}$ & $\begin{array}{l}\mathrm{R}=\mathrm{CH}_{3} \\
3.88\end{array}$ & $\begin{array}{c}\mathrm{R}=\mathrm{H} \\
-\end{array}$ & \\
\hline$O^{O R^{\prime}}$ & $\begin{array}{c}\mathrm{R}^{\prime}=\mathrm{H} \\
-\end{array}$ & $\begin{array}{l}\mathrm{R}^{\prime}=\mathrm{CH}_{3} \\
3.35\end{array}$ & $\begin{array}{l}\mathrm{R}^{\prime}=\mathrm{COCH}_{3} \\
1.97\end{array}$ & $\mathrm{~s}$ \\
\hline $\mathrm{CH}_{2}$ & $3.64^{\alpha)}$ & 3.42 & 4.10 & $t, J=8$ \\
\hline $\mathrm{CH}_{1}$ & $2.84^{a)}$ & 2.85 & 2.85 & $t, J=8$ \\
\hline$-\mathrm{OCH}_{3}$ & 3.76 & 3.86 & 3.73 & $\mathrm{~s}$ \\
\hline$-\mathrm{H}$ (aromatic) & $6.08^{b)}$ & 6.01 & 6.00 & s \\
\hline
\end{tabular}

a) Decoupling experiments were performed on these protons and the couplings were confirmed.

b) The irradiation at the proton resulted in the increase $(9.7 \%)$ of the signal at $\delta 3.76$.

11 on cyclisation by sulfuric acid treatment. ${ }^{3)}$ Although the optical activity of the naturally. occurring compound LL-D253y (11) was recorded, that derived from LL-D253 $\alpha$ was not shown. ${ }^{3}$ It is a well known fact that chromanones undergo the Wessely-Moser rearrangement in acidic condition. Thus there still remained the possibility of the formation of $\mathbf{1 1}$ from a compound having the structure 7. In order to confirm the problem the same reaction was repeated for our compound and the product was proved to be identical with 11 retaining the same optical activity (determined by $\mathrm{CD}$ ). Thus the structure of the chroma-

18) W. Gaffield, Tetrahedron, 26, 4093 (1970).

19) C. Takahashi, S. Sekita, K. Yoshihira, and S. Natori, the paper presented at the 92nd Annual Meeting of Pharmaceutical Society of Japan, Osaka, April 1972. 
none was firmly established as (2R)-5-hydroxy-6-(2'-hydroxyethyl)-7-methoxy-2-metliylchromanone. Recently another example of an optically active chromanone of fungal origin was reported. ${ }^{20)}$

\section{Experimental}

Culture and Culturing Conditions_-Fifteen strains of Phoma specjes, listed in Table I, were used for this study. The fungi were grown in $1000 \mathrm{ml}$ Roux flasks containing $200 \mathrm{ml}$ each of potato-dextrose medium (potato $300 \mathrm{~g}$, glucose $50 \mathrm{~g}$, and deionized water 1 liter). The inoculated flasks were incubated at $25^{\circ}$ for 3 weeks under stationary conditions. The mycelium and the filtrate were separated by filtration, the mycelium was immediately homogenized with $\mathrm{CHCl}_{3}$ in a warring blender, and the solvent was evaporated.

Toxicity Tests using HeLa Cells and Mice_- The methods were the same as those reported in the previous papers. ${ }^{4-6)}$ The filtrate and dimethyl sulfoxide solution of the mycelial extract were used for the tests. The results were summarized in Table $\mathrm{T}$.

Examination of the Metabolites by Thin-Layer Chromatography_-The filtrate was extracted succesiveIy with $\mathrm{CHCl}_{3}$ and EtOAc and the two extracts and the mycelial extract were used for the tests. Silica gel $\mathrm{HF}_{254}$ was employed for the absorbant, mixtures of $\mathrm{CHCl}_{3}-\mathrm{EtOAc}(1: 1)$ and $\mathrm{CHCl}_{3}-\mathrm{MeOH}(10: 1)$ were used as the developing solvents, UV lumps (254 and $365 \mathrm{~nm}$ ) and sulfuric acid were used for the detection, and phomin (1), dehydrophomin (2), and phomalactone ${ }^{13}$ ) were used for the standards. All fifteen strains: showed several spots but none of them were jdentical with the standards.

Isolation of Cynodontin from the Strain NHL 7017—. The chloroform extract of the mycelium (from 5 liter of medium) was passed over a silica gel column and a red-colored zone was collected. The fraction was dissolved in benzene and partioned with $5 \% \mathrm{NaOH}$. The alkaline layer was separated, acidified, and extracted with benzene. The benzene layer was washed with $5 \% \cdot \mathrm{NaHCO}_{3}$ and $5 \% \mathrm{Na}_{2} \mathrm{CO}_{3}$ and evaporated. The residue $(c a .50 \mathrm{mg})$ was recrystallized from $\mathrm{CHCl}_{3}$ to dark red crystals of $\mathrm{mp} 245^{\circ}$, UV $\lambda_{\max }^{\mathrm{CrCl}_{3}} \mathrm{~nm}(\log \varepsilon)$ : $295,490,514,524,550,564(3.99,4.07,4.25,4.32,4.30,4.37)$, IR $\nu_{\max }^{\mathrm{KBr}} \mathrm{cm}^{-1}: 1580,1440,1390,1270,1250$, $1170,1080,1020,970,790$. The identity with the authentic sample of cynodontin (3) was confirmed by TL.C and IR. It forms tetraacetate, yellow needles of $\mathrm{mp} 221-\mathbf{2 2 2 ^ { \circ }}$ from benzene.

Examination of Metaholites of the Strain NHL 7008_- The filtrate (from 10 liter of medium) was successively extracted with $\mathrm{CHCl}_{3}$ and EtOAc. The aqueous layer after extractions was absorbed on a charcoal column and successively eluted with water, $\mathrm{MeOH}$, acetone, and benzene. Each fraction was tested for cytotoxicity but none showed the activity. The EtOAc extract ( $7.6 \mathrm{~g}$ ) was chromatographed using silica: gel and eluted successively with benzene, benzene-EtOAc (8:2), benzene-EtOAc (1:1), $\mathrm{CHCl}_{3}-\mathrm{EtOAc}(1: 1)$, EtOAc, and $\mathrm{MeOH}$. From benzene-EtOAc (8:2) eluate 6-methylsalicylic acid (81 mg), $\mathrm{mp} 164^{\circ}$, was obtained and identified by IR and NMR.

From EtOAc fraction colorless needles $(55 \mathrm{mg})$ of $\mathrm{mp} 191-193^{\circ}$ was obtained; IR $\nu_{\max }^{\mathrm{KBr}} \mathrm{cm}^{-1}: 3550,1700$, $1680,1617,1580,1465,1440,1355,1300,1250,1225,1190,1170,1090,1055$; mass spectrum $(\mathrm{m} / \mathrm{e}):$ observed, 308.089; Calcd. for $\mathrm{C}_{15} \mathrm{H}_{16} \mathrm{O}_{7}: 308.089$. The methyl ether obtained by $\mathrm{CH}_{3} \mathrm{I}-\mathrm{Ag}_{2} \mathrm{O}$ showed mp $128-130^{\circ}$ (from AcOEt).

Isolation of the Chromanone (4) from the Strain NHL 7018__-The culture filtrate (from 3 liter medium) was extracted with EtOAc and the extract was passed over silica gel using $\mathrm{CHCl}_{3}, \mathrm{CHCl}_{3}-\mathrm{EtOAc}, \mathrm{EtOAc}$, and $\mathrm{MeOH}$ successively as the eluting solvents. From $\mathrm{CHCl}_{3}-\mathrm{EtOAc}$ fraction the chromanone (4) was obtained as colorless needles $(450 \mathrm{mg}), \mathrm{mp} 190-191^{\circ}$, after recrystallization from EtOAc, $\left[\alpha_{-}^{18.5}+24.8^{\circ}(c, 0.01\right.$, $\mathrm{MeOH}$ ) (lit. $\left..^{3)} \mathrm{mp} 188-189^{\circ},[\alpha]_{\mathrm{b}}^{25}+25.2 \pm 0.42^{\circ}(\mathrm{MeOH})\right) ; \mathrm{UV} \lambda_{\max }^{\mathrm{EtoH}} \mathrm{nm}(\log \varepsilon): 240,288,325(4.07,4.21,3.70)$, $\lambda_{\mathrm{max}}^{\mathrm{KOH}-\mathrm{EtOH}} \mathrm{nm}(\log \varepsilon): 253,328(3.86,4.34) ; \mathrm{IR} \boldsymbol{v}_{\max }^{\mathrm{KBr}} \mathrm{cm}^{-1}: 3320,1640,1590,1460,1390,1340,1290,1210,1160$, 1120, 1100, 1030; Mass Spectrum m/e: $252.096\left(\mathrm{M}^{+}\right.$, Calcd for $\left.\mathrm{C}_{13} \mathrm{H}_{16} \mathrm{O}_{5}: 252.100\right), 221\left(\mathrm{C}_{12} \mathrm{H}_{13} \mathrm{O}_{4}\right), 179$ $\left(\mathrm{C}_{9} \mathrm{H}_{7} \mathrm{O}_{4}\right)$.

Dimethyl Ether (5): The chromanone (4) $(50 \mathrm{mg})$ in $\mathrm{CHCl}_{3}(2 \mathrm{ml})$ was treated with $\mathrm{CH}_{3} \mathrm{I}(0.7 \mathrm{ml})$ and $\mathrm{Ag}_{2} \mathrm{O}(0.2 \mathrm{~g})$ at room temperature for $20 \mathrm{hr}$. After working up usual and purification by preparative layer chromatography colorless needles $(5)(28 \mathrm{mg})$ were obtained, $\mathrm{mp} 95^{\circ}$ (from hexane), IR $\nu_{\max }^{\mathrm{KBr}} \mathrm{cm}^{-1}: 1685$, $1600,1575,1475,1460,1355,1265,1210,1130,1080$; Mass Spectrum m/e: 280.126( $\mathrm{M}^{+}$, Calcd. for $\mathrm{C}_{15} \mathrm{H}_{20} \mathrm{O}_{5}$ : 280.131.)

Monoacetate (6): The chromanone (4) $(35 \mathrm{mg})$ was treated with $\mathrm{Ac}_{2} \mathrm{O}(2 \mathrm{ml})$-pyridine $(2 \mathrm{ml})$ at room temperature for overnight. Recrystallization from EtOAc gave colorless crystalls (6) (21 mg) of mp 207-

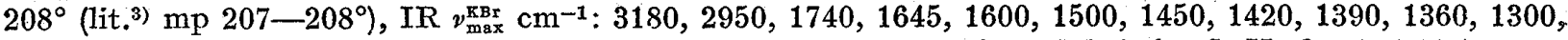
1240, 1210, 1155, 1120, 1090, 1030; Mass Spectrum m/e: 294.111 (M+, Calcd. for $\left.\mathrm{C}_{15} \mathrm{H}_{18} \mathrm{O}_{6}: 294.110\right)$.

Formation of the Dihydrofuran (11) from the Chromanone (4): The chromanone (4) (6.3 mg) was dissolved in conc. $\mathrm{H}_{2} \mathrm{SO}_{4}(0.1 \mathrm{ml})$. After standing at room temperature overnight, the solution was diluted with water

20) Ch. Tamm, B. Böhner, and W. Zürcher, Helv. Chim. Acta, 55, 510 (1972). 
and neutralized. The EtOAc extract was then purified by preparative layer chromatography. The spot showing the identical $R f$ value with LL-D253 $\gamma(\mathbf{1 1})$ was collected and the CD curves are compared.

Acknowledgement The authors indebted to Dr. E.L. Patterson, Lederle Laboratories, Dr. W.B. Turner, Imperial Chemical Industries, and Dr. T. Yamano, Takeda Chemical Industries, for their kind gifts of samples. The authors thank Dr. C. Murata, Takeda Chemical Industries, and Prof. M. Tomoeda, Kanazawa University, for their help in physical determinations, and Dr. M. Fukuoka and Mr. Kuroyanagi, this laboratory, for $\mathrm{CD}$ determination and discussion. 